\title{
INFORMATION AND COMMUNICATION TECHNOLOGY IN HIGHER EDUCATION: ONLINE EXPERIENCE OF FACULTY
}

\author{
Hira Saeed ${ }^{1}$, Dr. Shazia Naureen ${ }^{2}$, Dr. Sohaib Sultan ${ }^{3}$, Kainat $^{4}$ \\ ${ }^{1}$ MS Scholar, Department of Education, Faculty of Social Sciences, International Islamic University Islamabad, Pakistan \\ ${ }^{2}$ Incharge Department of Education, Faculty of Social Sciences, International Islamic University Islamabad, Pakistan \\ ${ }^{3}$ Assistant Professor, Department of Humanities Education \& Psychology, Faculty of Social Sciences, Air University, Islamabad, \\ Pakistan \\ ${ }^{4}$ MPhil Scholar, Department of Humanities Education \& Psychology, Faculty of Social Sciences, Air University, Islamabad, \\ Pakistan \\ Email: ${ }^{1}$ hirasaaed.msedu371@iiu.edu.pk, ${ }^{2}$ sohaib.sultan@mail.au.edu.pk, ${ }^{3} d r s h a z i a . n a u r e e n @ i i u i . e d u . p k$, \\ ${ }^{4} 191588 @$ students.au.edu.pk, ${ }^{5}$ kainatbatool1742@gmail.com
}

\begin{abstract}
Online teaching is a major concern in today's teaching process, and it is necessary to determine the impact of Information and Communication Technology (ICT) on online teaching. Currently, online teaching plays a vital role in guiding educators; students must be updated about the use innovation in the right way. Teachers must teach students about the correct use of technology. The purpose of the research were to study the on line experience of faculty with ICT to overcome the challenges in teaching learning process. The research was quantitative in nature whereas survey methods and quantitative questionnaire were utilized in current research. The random sampling technique was used to target the sample. The target population were the teachers who had experienced online courses and sample size $(n=100)$ teachers. Descriptive analysis were utilized by the researchers to analyze the collected data. The results of the research depicted that there is major role played in online teaching with Information and Communication Technology. Moreover online teaching, increase the use ICT for online courses, which relieved the teacher. The advantage of online teaching in this way is that students were not bound to place and time. COVID-19 stipulates that all instruction frameworks must be converted to online mode. It is recommended that appropriate training for teachers is mandatory, which will help them to implement ICT.
\end{abstract}

Keywords: ICT In Online Teaching, Use of ICT, and Faculty Experience

\section{Introduction}

In teaching and learning process, teachers play a key role. Different teachers use different teaching methods, which will benefit students from the overall teaching and learning activities. Traditional teaching methods are teacher-centered, such as lectures, while modern teaching methods are learneroriented (Gilbert, 2015). ICT plays an important role in online teaching technology. Because of COVID-19, the whole world has been infected, and the face to face education system around the world has been effected. In this case, teachers need to integrate computer technology into their online teaching. Lectures can be given in the form of PPT slides, reference material, activities, videos and assessments can save time and energy. No matter what course teachers and learners are studying, they can easily maintain the course. Display all information to see what is being taught (-Innes \& Wilton, 2018).

E-learning is using electronic technology to gain access to instructional educational programs. It implies a course, program or degree completed via the Internet. Up to now, online learning is inspiring social order around the world. In any case, everyone tends to use potential methods for school education. By the view of the existing limitations, elearning makes teaching adaptable and learning easier (Huang, 2018). Innovative progress is definitely changing the way people accept it. Educationist use innovation as much as possible to gain advantage for better learning. It can be seen that various online media such as Facebook, apps and Twitter play an important role in school education. In the new era, a lot of innovation is needed to get creativity. The communication between innovation and learning is inseparable in the 21 st century. It is essential to understand the role of innovation in training, which stimulates people's interest in school participation and in learning and creativity. Students can help each other, just like what they learned in university, using innovation (Nidhi Phutela, January 2019).

Online teaching and learning are usually practice in distance and blended education. Recently, it has attracted attention of schools and universities in the United States and abroad. Most universities and schools believe that preparation of ICT is essential to their education system. Online courses are best arranged when they are designed to shape the learning opportunities that are alternately supervised by online activities (Pavel, Fruth, \& Neacsuc, 2015). As individuals who have a career and need a lot of setup guidance are fascinated 
by Web-based preparations, the demand for guidance and the use of learning frameworks has been growing. Internet teaching makes learning more sensible and flexible, while standard instructional courses lack flexibility of time and space. The reason for attracting online courses is "to provide high-quality guidance to all learners, but little enthusiasm for region and time" (-Innes \& Wilton, 2018).

Online movement of learning can meet the needs of growing group of students. These students consolidate those who cannot attend ordinary classes, cannot find specific exercises in their chosen organization, live in more remote territories, work all day and can be said to be people who think at work or study after work (König, Jäger-Biela, \& Glutsch, 2020). The minimum needs of undergraduates taking online courses are access to PCs, the Internet, and the motivation to study in unconventional rooms. The online course provides an amazing programs and opportunities to every individual (Wang, 2008).

Countless universities abroad are changing from traditional eye tracking courses to completely online courses. Online teaching, usually called distance training or web-based teaching, is currently the latest and most famous type of distance training (Huang, 2018). Recently, it has become a vital part of many university courses. This article briefly introduces Internet education and learning. The Internet encouragement provides substantial opportunities for different learners to increase their learning atmosphere. With the increasing demand for online teaching, teachers can now be contacted to consider displaying prepared courses on the Internet. Online teaching imparts a lot of knowledge; however, it has very special arrangements in terms of abilities and prerequisites. The two methods are substantially comparable in terms of movement and transportation (Gilbert, 2015).

On a global scale, improved teaching (fairly referred to as $\mathrm{K}-12$ ) is a guide to employment sites to ensure a wide range of learning opportunities for students in the real mechanical field. The most effective method in teaching recently is to develop and confirm online preparation of courses as a truly high-quality learning institution. Online learning revolves around a wide range of invention-based learning stages, transmission methods, and the integration of teachers' advanced material into the center of the learning environment (Gilbert , 2015). The current progress has given option of creative universities at all levels, the opportunity to share their academic development in an atmosphere of improvement and support recognized strategies, but reformists are sufficient to allow these universities to conduct themselves in a self-directed manner. The online training ended with progressive guidance. Various educators have implied that online guidance is inherently practical, priceless and versatile (Hadadnia, Hadadnia and Shahidi, 2012).

Online teaching practices related to social, psychological, and cognitive presence are recognized. They must set learning conditions for instructive undergraduates, that they can plan educators and organize initial choices, changes to meet their desires for undergraduates. Because the tutoring needs of educators and the conditions for the tutoring system to work normally (König, Jäger-Biela, \& Glutsch, 2020).

Information and communication technology (ICT) is widely integrated into various teaching environments, bringing extraordinary changes in education and learning. Researchers believe that the development of online courses and curriculum products is changing the composition of teachers and the nature of education. Clarifying the role of teachers poses a huge challenge to analysts and experts (Huang, 2018).

In online teaching teachers were responsible to establish a convincing web-based learning environment, and should adopt the action method to successfully execute. Two teachers from a regular room environment will successfully change the online presentation, while other teachers may find advanced tests. Consider your way of appearance, conditions, and professional abilities to check whether authorization on the network is suitable for you. The online educator must be able to choose the same motivational learning estimate as the standard demonstration. Participants of effective online courses should advocate the promotion of learning and believe that learning can be promoted within the framework. Online moderators must be open, caring, versatile and sincere. Internet teachers should create a stable atmosphere to make all students in the virtual classroom feel shared, especially to make students realize that their educators are open, so as to create conditions for virtual rooms. Failure to do this may alienate the course from the educator and result in a weaker learning atmosphere (Hadadnia, Hadadnia and Shahidi, 2012).

E-learning is using electronic technology to gain access to instructional educational programs. It implies a course, program or degree completed via the Internet. Up to now, online learning is inspiring social order around the world. In any case, everyone tends to use potential methods for school education. In view of the existing limitations, elearning makes teaching adaptable. Following these lines of thinking, e-learning makes learning easier. Innovative progress is definitely changing the way people accept it (Nidhi Phutela, January 2019). Educated people and uncultivated people use innovation as much as possible to gain fun and advantage. It can be seen that various online media such as Facebook, apps and Twitter play an important role in school education. In the new era, a lot of innovation is needed to get creativity. The communication between innovation and learning is inseparable in the 21 st century. It is basic to understand the role of innovation in training, which stimulates people's interest in school participation and in learning and creativity. Just like well-learned in college, children can help each other to innovate (Wang, 2008). 
Online education had brought surprisingly imaginable results and great convenience. It is good for undergraduates and lecturers. It provides real-world comfort, cost efficiency and flexibility. Students with online teaching can search for degrees globally. Undergraduates who cannot take the standard exam and pass the setting have strengthened the network guidance. This is beneficial because it rewards people for thinking about ways to access anywhere on the Web (Shaheen Pasha, 2015). Online courses are open 24/7. In the past ten years, the total number of online courses has developed in a rapid manner. However, online coaching may be effective for everyone. Online teaching (in a simultaneous or non-concurrent manner) is linked to the entire need, which includes scheduling, computer programming, medicine, nursing, trade, music, and humanities. Online teaching has indeed become crucial in business alliances (Nidhi Phutela, January 2019).

Online teaching is the most important part of modern times. Recently, it has considered as an option in schools and universities. Most colleges and schools believe that the network plan is the basis of their framework design. When online courses are designed to provide learning opportunities that take advantage of online progress and guidance. Due to the premium for web-based planning by individuals who are engaged in a career and need a large number of set-up mentoring jobs, there is a growing demand for guidelines and learning structures (Hussain, Suleman, Naseer ud Din , \& Shafique, 2017).

\subsection{Statement of the Problem}

Nowadays, online teaching plays an important role in education. Teachers must learn and teach students how to use technology correctly. Teach them step by step, it will be easy for students to practice Information and Communication Technology tools. Therefore, students should practice it again and again, and then they will be able to understand and operate it in an effective way. Some schools or institutions did not have the appropriate technical tools. Due to the lack of tools teacher also lack practice, and skill development is also affected by this situation. Faculty members need to be trained properly to integrate online teaching. Therefore, this research was designed to investigate the experience of faculty in Information and Communication Technology at higher education level in Pakistan.

\subsection{Objectives}

The objectives of the research were:

1. To investigate the experience of teachers in online teaching.

2. To analyze teachers that are using online teaching to overcome the challenges in teaching and learning process.

\subsection{Research Questions}

1. What is the experience of teachers in online teaching?

2. How teachers are using online teaching to overcome the challenges in teaching learning process (due to COVID19)?

\subsection{Conceptual Framework of the Study}

The research were analyzing the teachers experience at university level on five basic parameters. These were: "Regular Assessment, on time Content Delivery, TeacherStudent Communication \& Availability of Technology."

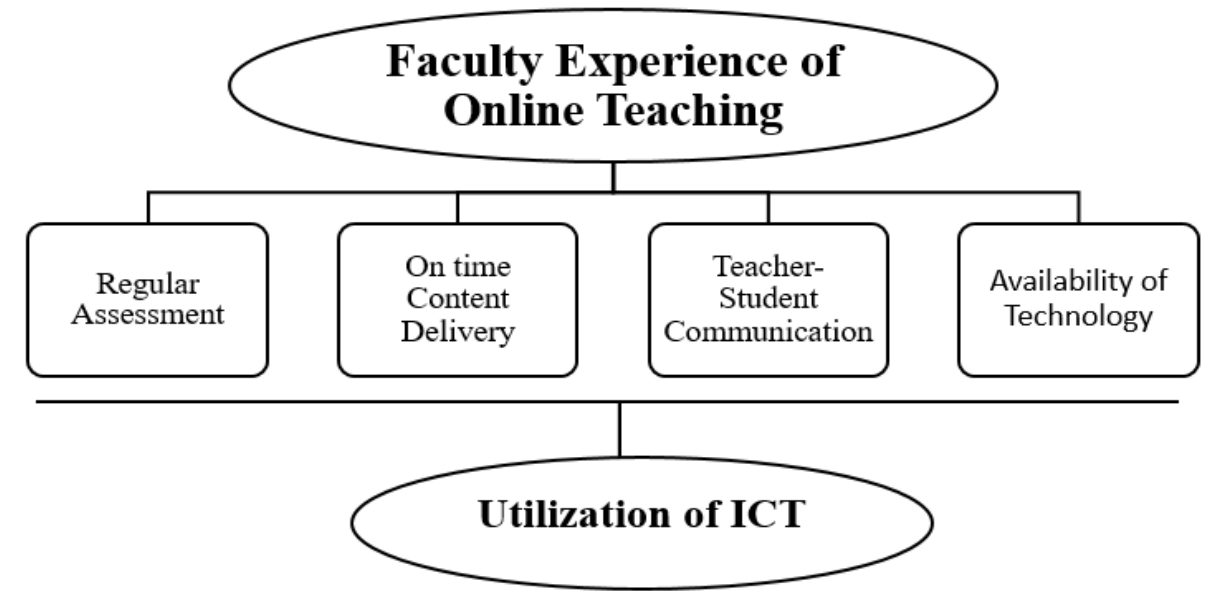

Figure 1.4: Framework for Information and Communication Technology in Higher Education with Online Teaching Experience of Faculty 


\section{Methodology}

Research was based on Quantitative method. Survey method design were utilized by the researchers for current research. As Survey research is defined as the process of conducting research using surveys sent by researchers to survey respondents. Then, conduct statistical analysis on the data collected from the survey to draw meaningful research conclusions. Population of this research were teachers who have experienced in online teaching. Three Public Universities were selected from Islamabad, Pakistan. Teachers who had experienced online classes from International Islamic University, Islamabad (IIUI), Quaid-e-Azam University, Islamabad (QAU), National University of Modern Languages (NUML) were requested to fill the questionnaire. The questionnaire with close ended questions were used for data collection. Questionnaires contained 20 statements from which 15 were close- ended questions with Likert scale from [(1 to 5) (Strongly Disagree to Strongly Agree)] and remaining 5 questions were in MCQs form. Statements in questionnaires were used to know about the experience of faculty members in online teaching. Due to Covid 19, researchers used snow ball sampling technique. Because universities were shifted to online mode and closed on campus. Therefore, researchers share the link with teachers that they share forward. The data was collected online by Google forms through which questionnaire. The number of respondents was 100 teachers, which is the sample size. The data collection time was 60 days. After the data collection results were analyzed by using SPSS (Version 23). Simple descriptive statistical technique was used for analyzing results.

\section{Data Analysis and Results}

\subsection{Statement Wise Analysis - Section A}

As section A was based on five point Linkert scale, there was specific percentage of respondents which agreed or disagreed the statements.

Table 3.1 Statement Wise Analysis

\begin{tabular}{|c|c|c|c|c|c|c|}
\hline Sr.\# & Statements & $S D$ & $D$ & $N$ & $A$ & $S A$ \\
\hline 1 & Online classes experience & - & - & - & 34 & 66 \\
\hline 2 & Teaching online & 2 & 11 & 24 & 38 & 25 \\
\hline 3 & Students attend online classes & - & 15 & 18 & 43 & 24 \\
\hline 4 & Online classes time saving. & - & 17 & 23 & 45 & 15 \\
\hline 5 & Students were responsive & & 10 & 22 & 64 & 4 \\
\hline 6 & Students are able to use computers for online classes. & - & 15 & 15 & 44 & 26 \\
\hline 7 & Timings for classes were observed. & - & 4 & 28 & 50 & 18 \\
\hline 8 & Time specified for classes was sufficient. & - & & & 51 & 49 \\
\hline 9 & Online classes were smoothly conducted. & 1 & 26 & 40 & 33 & - \\
\hline 10 & Student's behavior towards online classes & - & 17 & 58 & 25 & - \\
\hline 11 & Students were attentive and cooperative & - & 15 & 42 & 35 & 8 \\
\hline 12 & Assessments according to the students learning. & - & - & 2 & 54 & 44 \\
\hline 13 & Content delivery was according to the schedule. & - & 4 & 14 & 50 & 32 \\
\hline 14 & Technology was used effectively. & 1 & 7 & 17 & 39 & 36 \\
\hline 15 & Proper teaching methods & 2 & 12 & 24 & 37 & 25 \\
\hline
\end{tabular}

Above table presents that Respondent faculty members strongly agreed that they had great online teaching experience $(\mathrm{P}=66 \%)$. Moreover above table shows that teachers agreed that their students were responsive $(\mathrm{P}=64 \%)$. There were punctual as timings for classes were observed $(\mathrm{P}=50 \%)$, and there were time specified for classes was sufficient $(\mathrm{P}=51 \%)$, teachers had marked assessments according to the students learning $(\mathrm{P}=54 \%)$, and content delivery by them was according to the schedule planned by departments of universities $(\mathrm{P}=50 \%)$. Whereas teachers were neutral that the student's positive behavior towards online classes $(\mathrm{P}=58 \%)$.

\subsection{Mean Score Analysis}

Here is the mean score analysis of the statement of the questionnaire from section- A. 


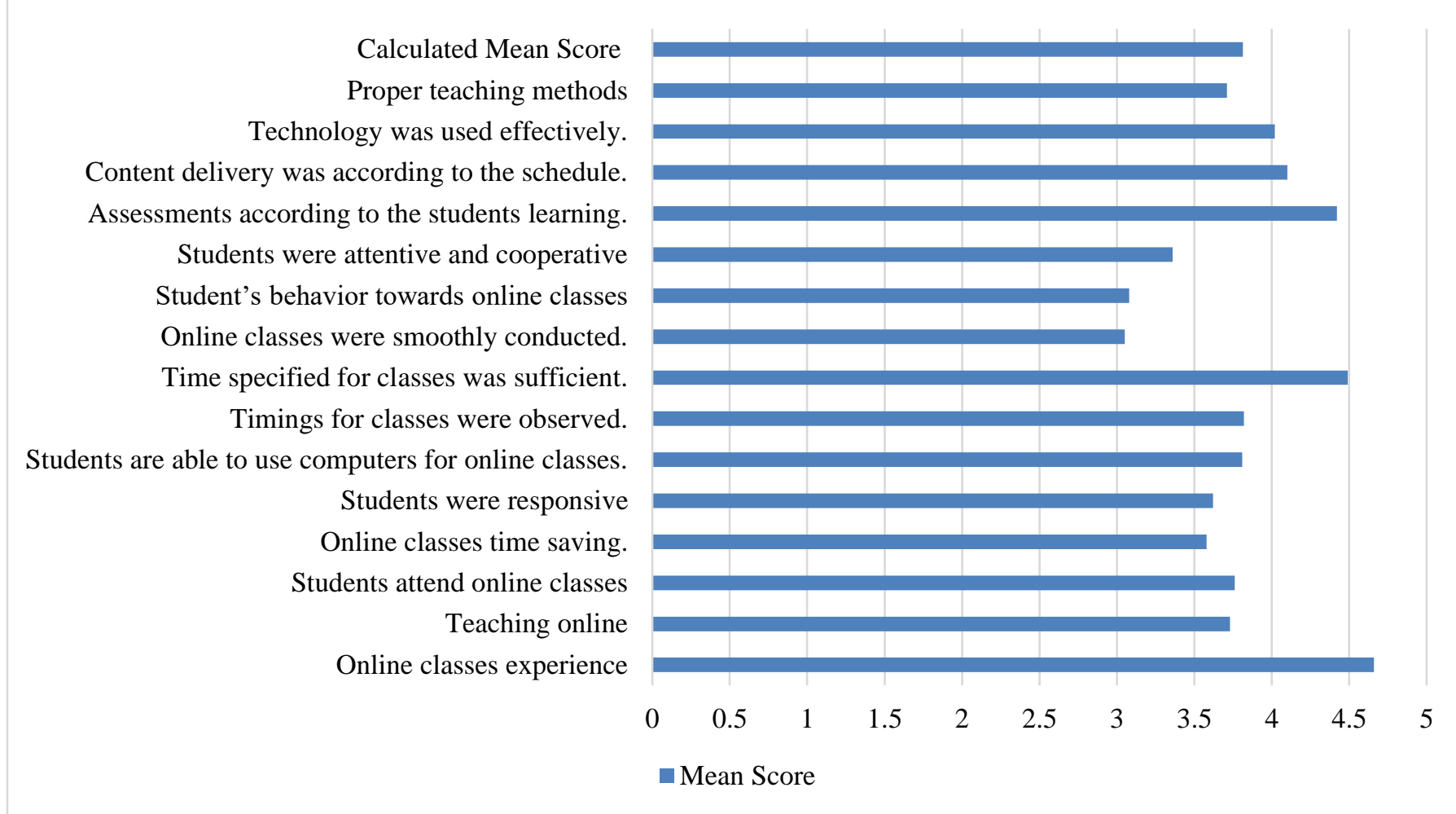

\section{Graph 3.2 Mean Score Analysis of the Items of Section-A}

Then graph presented that there were highest mean score observed at the statement that that they had get great online classes experience $(\mathrm{M}=4.66)$. Whereas lowest mean score were observed that smooth online classes were conducted by the teachers $(M=3.05)$. Moreover graph shows that students assessed by the teachers according to their learning (biased free assessment) $(\mathrm{M}=4.42)$. Technology were available to the faculty $(M=4.02)$ and content delivered to student was on the time as scheduled by the university departments $(\mathrm{M}=4.10)$. Overall concluded mean were $(\mathrm{M}=3.815)$ which shows that respondents agreed to the all statements.
Moreover mean score recorded in above graph shows that teachers were punctual and they assessed their students according to student's learning. Whereas teachers had faced problems as online teaching were not as smooth as it expected. Teachers had use ICT in online teaching to deliver lectures, communicate and assessed their students. Teachers had gathered great experience of online teaching by utilizing ICT.

\subsection{Section B Analysis}

Section B of the questionnaire was based of multiple choice question. Different option were marked by the respondents.

Table 3.3: Statement Wise Respondents Percentage - Section B

\begin{tabular}{|c|c|c|c|c|}
\hline Sr.\# & Questions & $\begin{array}{l}\text { Option A / } \\
\text { Percentage }\end{array}$ & $\begin{array}{l}\text { Option B / } \\
\text { Percentage }\end{array}$ & $\begin{array}{l}\text { Option C / } \\
\text { Percentage }\end{array}$ \\
\hline 1 & How often do students assessed within one semester? & $\begin{array}{c}\text { Just once } \\
4\end{array}$ & $\begin{array}{c}\text { Twice } \\
70\end{array}$ & $\begin{array}{l}\text { Several times } \\
26\end{array}$ \\
\hline 2 & How did you assess your students learning? & $\begin{array}{c}\text { Grades } \\
20\end{array}$ & $\begin{array}{l}\text { Points/Marks } \\
\quad 61\end{array}$ & $\begin{array}{l}\text { Percentages } \\
19\end{array}$ \\
\hline 3 & $\begin{array}{l}\text { How will you communicate if the students is not } \\
\text { performing }\end{array}$ & $\begin{array}{c}\text { Email. } \\
50\end{array}$ & $\begin{array}{l}\text { Telephone/cell } \\
39\end{array}$ & $\begin{array}{l}\text { Personal meeting } \\
\quad 11\end{array}$ \\
\hline 4 & E-learning platform used & Zoom & $\begin{array}{c}\text { Google } \\
\text { Classroom/Meet }\end{array}$ & Microsoft Teams \\
\hline & & 46 & 48 & 6 \\
\hline 5 & Which method you used lecture delivery? & Documents & $\begin{array}{l}\text { Audio lectures \& } \\
\text { Videos }\end{array}$ & Online/live class \\
\hline & & 46 & 13 & 41 \\
\hline
\end{tabular}


Above presented table shows the 70 percent of the respondents had twice assessed students within one semester twice. These results shows that teachers assessed their students twice but some of them assessed there students several times whereas few of them had assessed their students just one time. 61 percent of faculty members assessed their students learning by points and marks. It was reflected that most of the teachers assessed their students learning by marking in points. 50 percent teachers communicated through email if the students is not performing well. These results shows that most teachers communicate through email if the students were not performing. Table presents that the zoom used as E-learning platform by the teachers $(\mathrm{P}=46 \%)$, Google Classroom/Meet used as E-learning platform by the teachers $(\mathrm{P}=48 \%)$, whereas only $(\mathrm{P}=6 \%)$, of the respondents had used Microsoft Teams as E-learning platform. Different ICT tools were utilized by the teachers as E-learning platform most of the teachers had used zoom and google meet. Above table present that document were utilized by the teachers to deliver the lecture content $(\mathrm{P}=46 \%)$, Audio lectures \& Videos were utilized by the teachers to deliver the lecture content $(\mathrm{P}=13 \%)$, Online/live class were utilized by the teachers to deliver the lecture content $(\mathrm{P}=41 \%)$. The lecture were delivered by the teachers by sharing the documents and utilizing the live online Classes. The ICT utilization were increased during the online lecture.

\section{Conclusions}

The main purpose of research were to acknowledge the experiences of faculty in online teaching. It can be concluded that now a days ICT is playing a major role in teaching. As the results of the research ICT is being utilized in the teaching learning process. Teachers can use it in their teaching to improve the quality. Moreover research concluded that proper usage of technology in teaching learning process can lead towards better implication of knowledge. Along with teaching assessments were also carried out through online mode. Teachers communicated students' progress through Information and Communication Technology.

\section{Recommendations}

This research identifies the ICT in higher education with reference to experience of faculty in online teaching, the recommendations are as follows:

1. ICT should be made to be implemented by teachers and for this purpose proper training should be given to the teachers for effective implementation.

2. Blended courses may be offered other than face to face courses especially in Universities to develop ICT skills in students.

3. Teaching tutorials may be available on Learning Management System (LMS) regarding live sessions, uploading slides, recorded class lecture, assessment, material, and marking papers.

4. Tutorial training may be provided to students regarding joining online classes, utilizing online study resources, uploading assignments, and assessments through LMS

\section{References}

[1] Gilbert , B. (2015, April). Online Learning Revealing the Benefits and Challenges. Online Learning Revealing the Benefits and Challenges .

[2] Hadadnia, S., Hadadnia, N., \& Shahidi, N. (2012). Effects of Teaching through Online Teacher versus Real Teacher on Student Learning in the Classroom. CONTEMPORARY EDUCATIONAL TECHNOLOGY, Vol. 3, 50-59.

[3] Huang, Q. (2018). Examining Teachers' Roles in Online Learning. The EUROCALL Review, 3-18.

[4] Hussain, I., Suleman , Q., Naseer ud Din , M., \& Shafique , F. (2017, June). Effects of Information and Communication Technology (ICT) on Students' Academic Achievement and Retention in Chemistry at Secondary Level. Journal of Education and Educational Development, Vol. 4.

[5] -Innes, M. C., \& Wilton, D. (2018). Guide to Blended Learning.

[6] König, J., Jäger-Biela, D. J., \& Glutsch, N. (2020, August). Adapting to online teaching during COVID19 school closure: teacher education and teacher competence effects among early career teachers in Germany. European Journal of Teacher Education, Vol. 43.

[7] Nidhi Phutela, S. D. (January 2019). Impact of ICT in Education: Students' Perspective. SSRN Electronic Journal.

[8] Pavel, A. P., Fruth, A., \& Neacsuc, M. N. (2015). ICT and E-Learning - Catalysts for Innovation and Quality in Higher Education.

[9] Sadiku, M. N., Adebo, P. O., \& Musa, S. M. (2018). Online Teaching and Learning (Vols. Vol-8). United States. Retrieved 2020

[10] Shaheen Pasha, H. B. (2015). An Investigation of Teacher Education in Pakistan in Reference to Culturally. Journal of educational Sciences \& Research.

[11] Wang, Q. (2008). A generic model for guiding the integration of ICT into teaching and learning. Innovations in Education and Teaching International. 